\title{
Leveraging Financial and Non-financial Strategies for Shareholder Value Growth: A Study of Selected Hotels in Zimbabwe
}

\author{
Ngwenya Bongani* \\ Faculty of Business, Solusi University, Bulawayo, Zimbabwe \\ *Corresponding author: nbongani@gmail.com,ngwenyab@solusi.ac.zw \\ Received February 23, 2013; Revised March 21, 2013; Accepted April 24, 2013
}

\begin{abstract}
This study used a combination of quantitative and qualitative designs so as to gain a deeper insight on strategies used to achieve performance goals (shareholder value growth) in selected hotels in Zimbabwe. A self administered questionnaire was used to gather primary research data which was analyzed by the Statistical Package of Social Sciences (SPSS). The research findings were that all hotels use the financial, customer satisfaction, internal business processes, and innovation and learning strategies in order to achieve shareholder value growth. Apart from customer satisfaction, in which Hotel Group 3 recorded the highest mean of 4.5714 and Hotel Group 4 the lowest mean of 3.6667, the research has proved that generally all hotels apply the financial ad non-financial strategies in the same measure. The PE ratio was perceived to have performed superior with a mean of 3.7333 and standard deviation of 1.07146. EPS and dividend yield ratios also performed well with means of 3.7167 and 3.6500 respectively and standard deviations of 1.02662 and 1.03866 respectively. EPS is mostly driven by internal business process strategy as indicated by a significant correlation of .689 and to a lesser extent by financial strategy which had a correlation of .413. PE ratio had a significant correlation of .599 with internal business process strategy and a weaker correlation of .313 was recorded in financial strategy. Dividend yield growth, on the other hand, recorded a strong correlation of .553 with customer satisfaction strategy and a weaker correlation of .460 was noted with innovation and learning strategy. On the whole, the strongest correlation was found to be with internal business process strategy with an average mean of .611, followed by customer satisfaction strategy with a mean of .567 , innovation and learning strategy .499 and finally financial strategy with the least average correlation of .407 . EPS was affected by international business process strategy $(46.5 \%)$ and customer satisfaction strategy (10.3\%). Internal business process strategy had a $34.8 \%$ effect on PE ratio growth and dividend yield growth was affected by two factors, customer satisfaction strategy and financial strategy which contributed $29.4 \%$ and $12.2 \%$ respectively. The study revealed that, there is a relationship between hotel performance and strategies employed. Internal business process and customer satisfaction strategy had a bearing on the performance of the Earnings per Share (EPS), while dividend yield growth ratio was affected by customer satisfaction and financial strategies. On the other hand the Price Earnings ratio (PE) was affected by one factor only: internal business process strategy. Overall, internal business process strategy has been proven to have the strongest relationship while financial strategy has the weakest relationship.
\end{abstract}

Keywords: shareholder value growth, earnings per share, financial strategies, non-financial strategies, priceearnings ratio, share price

\section{Introduction}

Zimbabwe is a landlocked country in Southern Africa that is bordered to the south by South Africa, to the east by Mozambique, to the north by Zambia, and to the west by Botswana and Namibia. It has a population of 12,754,378 (July 2012 est.) with a total land area of $390,757 \mathrm{sq} \mathrm{km}$ [1]. After gaining independence on $18^{\text {th }}$ April 1980, Zimbabwe has been a relatively peaceful country. Endowed with a favourable warm tropical climate, the magnificent Victoria Falls (one of the Seven Wonders of the World), a diverse wildlife, ancient stone ruins, and other natural features, Zimbabwe is indeed a tourist paradise and a 'wanderlust' destination [2]. Tourism is arguably the world's largest and fastest growing industry [3] and the World Travel and Tourism Council (WTTC) expects travel and tourism to grow in importance as one of the world's highest priority sectors and employers, with an annual growth rate of $4 \%$ between 2011 and 2020 and a sectorial GDP increasing from US\$3.7bn to US\$104.7bn [4]. Most governments encourage the growth of tourism in their respective countries so as to support economic development [3]. As a developing continent, tourism is already a growing contributor to GDP and exports in more than half of all African countries and has been identified as a key sector for achievement of shared economic growth and poverty alleviation in Africa [5]. The importance of Africa's 
tourism industry is increasing with the world's highest growth rates for the 10 year annualized period to 2020 expected to come from the continent, fuelled by $5.7 \%$ and 4.7\% growths from North Africa and Southern Africa respectively [4]. It is projected that Zimbabwe tourism will grow by $9 \%$ annually leading to 2020 , contributing an average of $12 \%$ to the GDP. However, for this to be achieved there is need for the development of tourism infrastructure for ease of the provision of accommodation, excursions and transportation. Table 1 below shows a 10 year projection of tourism growth rates Worldwide.

Table 1. WTTC League Table Extract 10-Yr Real Growth

\begin{tabular}{|c|c|}
\hline Travel \& Tourism Economy GDP & Annualized,\% \\
\hline World & 4.4 \\
North Africa & 5.7 \\
Central\& Eastern Europe & 5.7 \\
Middle East & 5.2 \\
Latin America & 5.1 \\
Sub Saharan Africa & 4.7 \\
Oceania & 4.4 \\
North America & 3.9 \\
European Union & 2.9 \\
Other Western Europe & 2.5 \\
\hline
\end{tabular}

Source: WTTC

Realizing the contribution of tourism to the national economy, the Zimbabwe government launched a Short Term Emergency Recovery Programme (STERP) in March 2009, to get the Zimbabwean economy moving again. Some of the measures included incentives for investment into tourism such as duty exemption on capital goods for expanding, modernizing, and renovating registered designated tourist facilities or for the procurement of new equipment (Zimbabwe budget, 2009 \& STERP, 2009). STERP was revised in January 2010, giving the country a comprehensive capacity based rehabilitation programme or STERP II. In the same year, the United Nations (UN) and leading international developmental agencies came up with the Millennium

Independent Variables
Developmental Goals (MDGs), which are eight goals that are employed to eradicate global poverty by developing global partnerships for development. The MDGs and STERP have since been used as the basis for the development of the Medium Term Plan (MTP) for 2010 to 2015. The objective of the MTP is to enhance Zimbabwe's domestic, regional, and international tourism and make Zimbabwe a destination of choice (MTP, 2010). According to the World Heritage Sites and Sustainable Tourism Report (2010), the Victoria Falls were classified a World Heritage Site in 1989. It is shared by Zambia and Zimbabwe, and extends over 6,860ha, [Mosi-Oa-Tunya National Park (Zambia) 3,779ha; Victoria Falls National Park (Zimbabwe), 2,340ha; Riverine strip of Zambezi National Park (Zimbabwe), 741ha of the remaining area is considered as a buffer zone] on either side of the Zambezi River in the Southern part of Zambia and North-Western part of Zimbabwe. In the SADC region, the Victoria Falls World Heritage Site is the main tourist destination. It appears as if this was the thought in mind when the UN selected Victoria Falls as the venue for the UNWTO $20^{\text {th }}$ General Assembly scheduled to be held in August 2013. For its part, the government, through the Ministry of Finance, has set aside US\$2.1 million towards supporting various tourism promotional programmes in 2012, US\$1 million for preparations towards co-hosting the UNWTO assembly, while financing the cost of re-branding Zimbabwe tourism under the theme "Zimbabwe - A Wonder of Wonders" (National Budget Statement, 2012). It is hoped that these measures will assist the government market the country's tourist attractions and help increase tourism revenue inflows and with it accelerate the recovery of tourism in Victoria Falls in particular and Zimbabwe in general. Hotels, on their part, should align their organisational strategies to growing shareholder value. Figure 1 below shows the conceptual framework of the study.

Dependent Variables

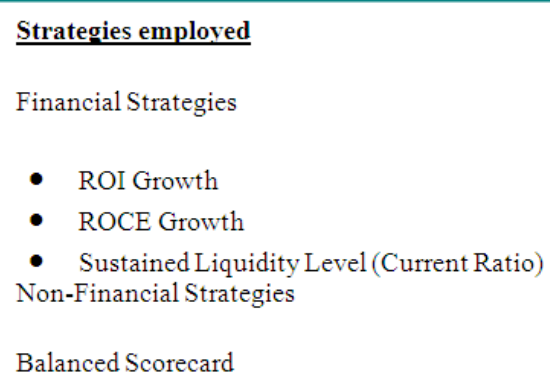

Business performance goal perception

Shareholder Value Growth

- EPS Growth

- PE Ratio Growth

- Dividend Yield Ratio Growth

Figure 1. conceptual framework of the study

The study sought to answer the following questions:

1. What business strategies do hotels employ to achieve shareholder value growth?

2. What is the perceived performance in terms of EPS, $\mathrm{PE}$ ratio, and dividend yield ratio?

3. Is there a relationship between hotel performance and their business strategy?

4. What factors affect hotel performance?

Share holder value growth is a performance strategy measure. Like any other nature of business, management for hotel industry strives to satisfy shareholders by focusing on those actions that will result in the maximisation of the wealth of the shareholders. As a result there is generally a relationship between shareholder value growth and the business strategies employed by management. It is from the research questions highlighted above and the propositions made that the researcher proposed the following hypothesis.

$\mathrm{H}_{1}$ : There exist a significant relationship between hotel's shareholder value growth and the business strategies employed by the hotel. 


\section{Literature Review}

\subsubsection{Return on Investment (ROI)}

Most businesses exist to maximize wealth for its stockholders. In this regard, the operating success of the business is measured by its profitability over a given period of time. The basic measure for evaluating the performance of capital investments is the return on investment (ROI), which always is expressed as a percent [20].

$$
\mathrm{ROI} \%=\frac{\text { Return }}{\text { Capital Invested }}
$$

\subsubsection{Return on Capital Employed (ROCE)}

Firms can raise investment capital from either internal or external sources. The internal sources of capital are retained earnings while external sources of capital are debt or equity. Whether the firm borrows money or raises it from shareholders is influenced by the cost of capital and the expectations of the investors. Debt is a more commonly used source of external capital and has lower transaction costs [21]. Although debt capital is cheaper than equity, a mix of both debt and equity provides firms with a good balance of capital. An adequate return on capital employed is what many investors seek and is, therefore, one of the main reasons why people invest their money in a business in the first place [22]. ROCE measures the rate at which shareholders' funds generate income from operating activities, excluding income and expenses from financing activities [23] and is calculated as follows;

$$
\text { ROCE }=\frac{\text { Net Profit }}{\text { Capital Employed }} \times 100
$$

Investors prefer to invest in companies with a high ROCE as these are deemed to be putting capital to good use. A declining ROCE, however, may point to a loss of competitive advantage and is unattractive to investors.

\subsubsection{Current Ratio}

A company's current ratio is the most important indicator of its current and prospective liquidity position and is used to measure the firm's ability to pay off shortterm debt as they come due [23,24]. It is used to compare total current assets to total current liabilities and indicates whether there are sufficient short-term assets to pay the short-term liabilities [22]. It is calculated by dividing current assets by current liabilities and is used to test the short-term liability-paying ability of a business [20].

$$
\text { Current Ratio }=\frac{\text { Current Assets }}{\text { Current Liabilities }}
$$

The general expectation is that the current ratio for a business should be 2 to 1 or higher and most short-term creditors prefer dealing with a business that carry current liabilities that are half or less compared to the value of the current assets [20]. A low current ratio indicates that the firm is likely to have liquidity problems in the year ahead. A high current ratio, on the other hand, may not be healthy as it may signal large inventory and trade debtors.
Although ratio analysis is a very useful technique for evaluating financial performance [25] it is advised that it may not be a good indicator as there are other nonfinancial variables at play. It is more effective if other performance measures are assessed for their effectiveness in the attainment of performance goals, and this is what the researcher sought to do in this study.

\subsection{Non-Financial Measures of Performance}

The PE ratio shows how much investors are willing to pay per dollar of reported profits such that a low PE ratio may signal an undervalued stock or may reflect a pessimistic forecast by investors for the future earnings prospects of the business while a high PE ratio may reveal an overvalued stock or reflect an optimistic forecast by investors [20,22]. It is very useful when a company proposes an issue of new shares, in that it enables potential investors to better assess whether the expected future earnings make the share a worthwhile investment [22]. Generally speaking a company's PE ratio is compared to industry and market ratios to see if they are high, low or within the range. Although financial strategies are very useful technique for evaluating financial performance, literature [25] counsels that these may not be a good indicator as there are other nonfinancial variables at play. Financial measures alone have proved inadequate in assisting companies attain their strategic performance goals, let alone steer a company through difficult times [26]. In recent years, it has become clear that a company's most important assets are not the ones that accountants measure [27], but even those that cannot be quantified. This has led companies to rely on non-financial performance measures and the balanced scorecard is the non-financial performance strategy in vogue these days.

\subsubsection{The Balanced Scorecard (BSC)}

The BSC is a modern performance measure first introduced to the business world by Robert Kaplan and David Norton, at the Harvard Business School, in 1992. It came about as a result of coming up with a performance measurement system that addressed the deficiencies of the former performance measurements and its various forms have been widely adopted across the business world [28] having evolved from the $1^{\text {st }}$ generation through the $2^{\text {nd }}$ generation and up to the $3^{\text {rd }}$ generation BSC. It is regarded as a strategic destination statement drawn by the company describing what the organization is likely to look like at an agreed future date [29] and unlike the financial and nonfinancial performance measurements, the BSC incorporates the benefits from both performance measurements and also other variables that are intangible, namely the financial, customer, innovation and learning perspectives.

Although it is agreed that financial variables alone may not be a sufficient measure of corporate performance, other authors suggest that it is only suitable for top managers in an organization and complicates the decision making and performance evaluation processes [30,31,32]. Its ability to simultaneously monitor the financial results and the effect of intellectual assets on future business grow has made it popular over the years [33]. Initially focused on finding a way to report on leading indicators of 
a business's health rather than traditional accounting measures which are lagging indicators, the balanced scored was refocused to measure the firm's strategy. Instead of measuring anything, firms should measure those things that directly relate to the firm's strategy [33]. The BSC [34] is understood as a system for performance measurement that links the company's strategy to specific goals and objectives, provides measures for assessing progress towards these goals, and indicates specific incentives to achieve these goals. The BSC looks at the firm from four perspectives (views): the financial perspective, the customer perspective, the business process perspective, and the learning and growth perspective [35]. These views are graphically illustrated below. Table 2 below depicts the Balanced Score Card (BSC) as summarised in literature [36].

The BSC does not disregard the traditional need for financial data by using them as a basis for strategizing a desired future financial position. For the purposes of this study we look at the non-financial perspectives that drive financial performance, namely customer satisfaction, internal business process and innovation and learning perspectives.

Table 2. BSC perspectives, strategy and measure

\begin{tabular}{|c|c|c|c|}
\hline \multicolumn{2}{|r|}{ Perspectives } & Strategy & Measure \\
\hline \multirow{2}{*}{1} & \multirow{2}{*}{ Financial } & Improve shareholder perception & - Net income, ROI, ROA, EVA, RI \\
\hline & & Reduce risk & - Higher credit rating \\
\hline \multirow[t]{2}{*}{2} & \multirow[t]{2}{*}{ Customer } & Improved customer relations & $\begin{array}{l}\text { - Customer orientation } \\
\text { - Number of return customers } \\
\text { - Customer satisfaction }\end{array}$ \\
\hline & & Increased orders from profitable customers & $\begin{array}{l}\text { - Market share } \\
\text { - Customer profitability }\end{array}$ \\
\hline \multirow{3}{*}{3} & \multirow{3}{*}{ Business Process } & Improved supplier relations & $\begin{array}{l}\text { - Number of vendors } \\
\text { - } \% \text { of on-time deliveries }\end{array}$ \\
\hline & & Improved quality of manufacturing process & $\begin{array}{l}\text { - Standard cost variance } \\
\text { - } \% \text { of orders filled } \\
\text { - Scrap as a } \% \text { of raw materials }\end{array}$ \\
\hline & & Improve delivery & - Number of on-time deliveries \\
\hline \multirow{3}{*}{4} & \multirow{3}{*}{ Learning and Growing } & Improve retention of employees & $\begin{array}{l}\text { - Turnover } \\
\text { - Employee satisfaction } \\
\end{array}$ \\
\hline & & Increase employee productivity & $\begin{array}{l}\text { - Hours of employee training } \\
\text { - Number of } \$ \text { cost savings from improvements }\end{array}$ \\
\hline & & Increase new product development & $\begin{array}{l}\text { - Number of new patents } \\
\text { - } \% \text { of sales from new products }\end{array}$ \\
\hline
\end{tabular}

\subsubsection{The Customer Satisfaction Perspective}

In his article, Corporate Strategy Today, Fiskel writes that the Customer perspective stresses understanding and satisfaction of changing customer needs and expectations [37]. The author further emphasised that many services are stored in systems, buildings, machines, knowledge and people and the normative goal of the firm should be to maximise value to the customer [38]. Understanding that no two customers are the same and thus by definition will have unique demands or experience the service in a unique way, standardisation is not even desirable for many services as most individuals appreciate customisation to meet their specific needs [39,40]. Satisfied customers generate repeat business and referrals, which in turn improved the profit margin; the reverse is true for unhappy customers. It becomes paramount for businesses to identify drivers that will increase on customer satisfaction and work on improving these. It is no wonder then that recent corporate management philosophy focuses on customer satisfaction in any business by seeking to understand their customer wants $[41,42]$. In order to better satisfy the target market, companies should identify their market segments and work on growing their market share, customer retention, customer acquisition, customer satisfaction, and customer profitability measurements [33].

\subsubsection{The Internal Business Process Perspective}

For a company to succeed, it has to identify those business processes that are critical for success, and this is especially true for businesses in the service industry.
Quality and productivity cannot be dealt with separately, especially when looking at services [43]. As such it is important that managers develop work processes that minimize costs while maximizing in quality [44]. Much of what makes a service special derives from the fact that it is a lived-through event and quality evaluations are not made solely based on the outcome, but also involve evaluations of the process of delivery, and the value profit chain $[45,46]$. The authors further propose the following seven value chain factors linking organizational performance with its profits as follows:

- Input quality drives employee satisfaction

- Employee satisfaction drives loyalty

- Employee loyalty drives productivity

- Employee productivity drives value

- Output value drives customer satisfaction

- Customer satisfaction drives loyalty; and

- Customer loyalty drives profitability and revenue growth.

\subsubsection{The Innovation and Learning Perspective}

The tourism industry is labour intensive. Salaries, benefits and other social expenses represent about $80 \%$ of total operational costs [47]. Learning is, therefore, necessary for continuous development, and hotels have to continually learn from their business processes and interactions with customers (both internal and external). Change is constant, and corporations should be in a continuous learning mode conducive for innovation and development. The learning is imperative and should be developed as a future human resource investment for the 
company [45]. However, for this to be possible, employees need to be satisfied, retained, and their productivity measured. To grow shareholder value, it is imperative then that hotels deliver service that competitors cannot deliver, or excel in service delivery where others are struggling. The recruitment, selection, and training of old and new employees can assist in horning the learning and innovation perspective. Over many years, studies have indicated a high correlation between innovation and shareholder value [48].

\subsection{Shareholder Value Maximisation}

The owners of a company are its shareholders and for large corporations, shareholders can be so numerous that it becomes impossible for the shareholders to run the enterprise on their own. For that reason management teams are employed to run the company on behalf of the shareholders and the shareholders delegate their authority to a board of directors to have a day-to-day oversight on the operation of the business. Shareholder investment is informed by different expectations and preference and these should be incorporated in formulating corporate objectives. Corporate objectives or goals are numerous and they include profit maximisation, sales maximisation, growth maximisation, and wealth maximisation. Whatever objective are set, they should leave or make the firm stakeholders better off both in the short and long-term. In short, the primary objectives of a firm are to maximise its market value by employing business strategies that seek to increase its present value and economic profits. Managers as a general rule will act to maximize the value of the firm to its stockholders and management teams that deviate too far from this rule are likely to be replaced. They go on to say that "smart and effective financial manager makes decisions which increase the current value of the company's shares and the wealth of its stockholders [49].

Wealth maximization is the common objective that most shareholders unite under. However, shareholder wealth can only be maximized if shareholder value is maximized. In a free market economy a firm is unlikely to survive if it pursues goals that reduce the firm's value [49]. The value of an organisation can be gauged from two different angles; value-adding managers and valuedestroying managers [50]. Value adding managers are considered to be those who create value by increasing the company's value relative to the cost of capital at their disposal and value destroying managers are those whose accounting investments exceed the market value of their business. Shareholder value is maximised through the cash shareholders receive in dividend payment and also capital gains arising from increasing share price [51]. Shareholder value is difficult to influence directly by any manager, it is usually broken down into components, commonly referred to as value drivers [52]. They go on to write that the widely used model comprises seven drivers of shareholder value are as follows:

- Sales growth

- Operating profit margin

- Effective tax rate

- Incremental investments in capital expenditure

- Investment in Working Capital

- Competitive Advantage Period (value growth duration)
- Cost of Capital

The most common shareholder growth measures are EPS, PE ratio, and the dividends yield ratio.

\subsubsection{Earnings per Share (EPS) Growth}

An Earnings per Share is the most used accounting ratio by listed companies. It indicates how much of a company's profit can be attributed to each ordinary share in the company over a period of time. EPS is calculated by dividing the net profit or loss attributable to ordinary shareholders by the weighted average number of ordinary shares outstanding during the period [43].

$$
\text { EPS }=\frac{\text { Profit after tax }}{\text { Number of shares }}
$$

An increase in profits, ceteris peribus, will result in an increase in EPS while an increase in the number of shares issued, ceteris peribus, will reduce EPS. Private businesses do not have to declare their EPS, but for listed companies declaring EPS is mandatory. Although calculating EPS seems straight forward, there are technical issues that have to be considered for example which number of shares to use as a denominator; number of issued shares or number of authorised shares. It follows then that EPS can be calculated from two approaches and these are basic EPS and diluted EPS. Basic EPS is computed by dividing a company's profit by the number of shares issued, while, diluted EPS, on the other hand, is computed by dividing profit by not only the authorised shares but takes also into account additional shares of stock that may be issued for stock options granted by a business and other stock shares that a business is obligated to issue in the future [32]. As far apart as these figures may seem, in practice the two EPS figures are not that far apart, but close. EPS is affected by not only the prior year profits but other economic shocks like inflation, profit plowbacks, and ROE.

\subsubsection{Price Earnings (PE) Growth}

$\mathrm{PE}$ ratios are one of the most used ratios by financial analysts when selecting cheap value stocks relative to EPS. They may be regarded as forward-looking or backwardlooking PEs. Forward-looking PEs are estimated on the basis of expected EPS (usually for the next four quarters) and trailing PEs on the basis of observed EPS (usually the last four quarters) [53]. It is a very useful indicator of how the stock market assesses the company by relating the earnings per share to the market price of the shares [32]. It is the ratio of the current stock price to prior year's earnings per share [54], usually 5-10 years, and is calculated by dividing the market value of shares by the EPS.

$$
\mathrm{PE}=\frac{\text { Market Value of Shares }}{\text { Earnings per Share }}
$$

\subsubsection{Dividend Yield Ratio Growth}

A firm has to decide whether to plough back profits as retained earnings or pay put earnings to its shareholders. If the decision is to pay out earnings to shareholders, the payments can either be made in the form of dividends or capital gains through stock repurchases. Dividends can be 
paid as regular or special cash dividends. Stock repurchases, on the other hand, can be made directly from the market, through a tender offer to shareholders or by negotiating privately with a group of shareholders. In practice, however, shareholders are paid through regular cash dividends. Large dividend payments results in low retained earnings opening the firm to possible heavy external financing for future investments. Small dividend payments are compensated by retained earnings and with it a possibility of low external financing for future investment. Dividends are said to have a signalling effect in that they are paid when the firm is positive about its future financial performance.

The dividend yield ratio measures the real rate of return by comparing the dividend paid to the market price of a share [34]. It is calculated by dividing cash dividends paid by a business over the most recent 12 months (called the trailing 12 months) by the current market price per share of the stock [54].

$$
\text { Dividend Yield }=\frac{\text { Dividend paid per share }}{\text { Market value per share }}
$$

There is a strong correlation between EPS and dividend yield ratio. EPS growth directly results in dividend yield growth and the reverse is true for a decline. It is important to note that companies compensate their investors by paying out dividends or growing the value of the stock (capital gains). High dividend-yield stocks, therefore, are not necessarily better investments options than low-yield stocks since low dividends can offer greater prospects for capital gains [34]. Whatever the size of the dividends, they put immediate cash into the hands of shareholders and are paid where the firm feels it has more cash than its future investments demand.

\section{Research Methodology}

The research was designed to gather both qualitative and quantitative data. It was descriptive in nature. A sample of 70 drawn from a population of 140 participated in the research study. This sample was selected through stratified sampling and a random sample collected from each stratum. From the sample of 70 , only 60 responses were received. The variables for the study were rated on a scale of 1-5, with 5 being the highest score. A mean was used as a measure of central tendency and a standard deviation computed to find the deviation from the mean.

\section{Analysis of Data}

This chapter presents the research findings in statistical terms. It gives an analysis and interpretation of the data gathered to inform the study.

\subsection{Research Question 1}

What business strategies do hotels employ to achieve shareholder value growth?

\subsubsection{Financial Strategies}

The descriptive statistics and ANOVA for financial strategies are as follows (see Table 3 and Table 4).
Table 3. Descriptive Statistics on Financial Strategies Employed

\begin{tabular}{|c|c|c|c|c|}
\hline & $\mathbf{N}$ & Mean & Std. Deviation & Std. Error \\
\hline $\begin{array}{c}\text { Hotel } \\
\text { Group 1 }\end{array}$ & 30 & 3.8000 & .80990 & .14787 \\
\hline $\begin{array}{c}\text { Hotel } \\
\text { Group 2 }\end{array}$ & 17 & 3.6667 & .70711 & .17150 \\
\hline $\begin{array}{c}\text { Hotel } \\
\text { Group 3 }\end{array}$ & 7 & 4.3333 & .69389 & .26227 \\
\hline $\begin{array}{c}\text { Hotel } \\
\text { Group 4 }\end{array}$ & 6 & 3.8889 & .17213 & .07027 \\
\hline Total & $\mathbf{6 0}$ & $\mathbf{3 . 8 3 3 3}$ & $\mathbf{. 7 4 0 2 9}$ & $\mathbf{. 0 9 5 5 7}$ \\
\hline
\end{tabular}

Table 4. Financial Strategy ANOVA

\begin{tabular}{|c|c|c|c|c|c|}
\hline & $\begin{array}{c}\text { Sum of } \\
\text { Squares }\end{array}$ & $\mathrm{df}$ & $\begin{array}{c}\text { Mean } \\
\text { Square }\end{array}$ & $\mathrm{F}$ & Sig. \\
\hline $\begin{array}{c}\text { Between } \\
\text { Groups }\end{array}$ & 2.274 & 3 & .758 & 1.412 & .249 \\
\hline $\begin{array}{c}\text { Within } \\
\text { Groups }\end{array}$ & 30.059 & 56 & .537 & & \\
\hline Total & 32.333 & 59 & & & \\
\hline
\end{tabular}

Most hotels employ the use of financial strategy as evidenced by the overall mean score of 3.8333 and a standard deviation of 0.7409 from the mean. The analysis of the data indicates that all hotel groups under study apply the financial strategies as a tool of adding shareholder value on the same degree as indicated by a significance level of .249 (Table 4).

Hotel Group 3 has the highest mean of 4.3333 and a standard deviation of .69389 for its application of financial strategies. Hotel Group 1 has the second highest mean of 3.8000, followed by Hotel Group 2 on 3.8889, and finally Hotel Group 4 on a mean of 3.6667 all at a significance level of .249.

\subsubsection{Customer Satisfaction Strategy}

Table 5 and Table 6 below give descriptive statistics and ANOVA for customer satisfaction strategy.

Table 5. Descriptive Statistics of Customer Satisfaction Strategy

\begin{tabular}{|c|c|c|c|c|}
\hline & $\mathbf{N}$ & Mean & Std. Deviation & Std. Error \\
\hline $\begin{array}{c}\text { Hotel } \\
\text { Group 1 }\end{array}$ & 30 & 4.3333 & .56051 & .10234 \\
\hline $\begin{array}{c}\text { Hotel } \\
\text { Group 2 }\end{array}$ & 17 & 4.0392 & .74426 & .18051 \\
\hline $\begin{array}{c}\text { Hotel } \\
\text { Group 3 }\end{array}$ & 7 & 4.5714 & .46004 & .17388 \\
\hline $\begin{array}{c}\text { Hotel } \\
\text { Group 4 }\end{array}$ & 6 & 3.6667 & 1.03280 & .42164 \\
\hline Total & $\mathbf{6 0}$ & $\mathbf{4 . 2 1 1 1}$ & $\mathbf{. 6 9 1 5 3}$ & $\mathbf{. 0 8 9 2 8}$ \\
\hline
\end{tabular}

Table 6. Customer Satisfaction Strategy ANOVA

\begin{tabular}{|c|c|c|c|c|c|}
\hline & $\begin{array}{c}\text { Sum of } \\
\text { Squares }\end{array}$ & df & $\begin{array}{c}\text { Mean } \\
\text { Square }\end{array}$ & F & Sig. \\
\hline $\begin{array}{c}\text { Between } \\
\text { Groups }\end{array}$ & 3.638 & 3 & 1.213 & 2.763 & .050 \\
\hline $\begin{array}{c}\text { Within } \\
\text { Groups }\end{array}$ & 24.577 & 56 & .439 & & \\
\hline Total & 28.215 & 59 & & & \\
\hline
\end{tabular}

A mean score of 4.2111 and a standard deviation of 0.69153 portray a strong use of customer relations across all hotel groups. Given a significance level of 0.05, Hotel Group 1 employs more customer satisfaction strategy with a mean score of 4.5717 and a standard deviation of .46004, when compared to other hotel groups. Hotel Group 4 has the lowest usage of customer satisfaction as a strategy of 
adding shareholder value, with a mean score of 3.6667 and a standard deviation of 1.03280. Hotel Group 1 and 2 have the second and third highest application of customer satisfaction strategies as indicated by means of 4.3333 and 4.0392 and standard deviations of .56051 and .18051 respectively. It is concluded that not all hotels regard their customers as critical to shareholder value addition. Research, however, indicate that customer care is critical not only for generating current cash flows, but for longterm financial gains as well.

\subsubsection{Internal Business Process strategy}

The descriptive statistics and ANOVA of internal business process are highlighted in Table 7 and Table 8 below.

Table 7. Descriptive Statistics of Internal Business Strategy

\begin{tabular}{|c|c|c|c|c|}
\hline & N & Mean & $\begin{array}{c}\text { Std. } \\
\text { Deviation }\end{array}$ & $\begin{array}{c}\text { Std. } \\
\text { Error }\end{array}$ \\
\hline Hotel Group 1 & 30 & 4.2333 & .70385 & .12850 \\
\hline Hotel Group 2 & 17 & 4.2500 & .58630 & .14220 \\
\hline Hotel Group 3 & 7 & 4.5714 & .47246 & .17857 \\
\hline Hotel Group 4 & 6 & 4.0000 & .77460 & .31623 \\
\hline Total & $\mathbf{6 0}$ & $\mathbf{4 . 2 5 4 2}$ & $\mathbf{. 6 5 4 9 9}$ & $\mathbf{. 0 8 4 5 6}$ \\
\hline
\end{tabular}

Table 8. Internal Business Strategy ANOVA

\begin{tabular}{|c|c|c|c|c|c|}
\hline & $\begin{array}{c}\text { Sum of } \\
\text { Squares }\end{array}$ & df & $\begin{array}{c}\text { Mean } \\
\text { Square }\end{array}$ & F & Sig. \\
\hline $\begin{array}{c}\text { Between } \\
\text { Groups }\end{array}$ & 1.106 & 3 & .369 & .853 & .471 \\
\hline $\begin{array}{c}\text { Within } \\
\text { Groups }\end{array}$ & 24.206 & 56 & .432 & & \\
\hline Total & 25.311 & 59 & & & \\
\hline
\end{tabular}

Internal business processes include the usage of service quality, supplier relations and delivery, among other variables. The research produced an overall mean score of 4.2542 and a standard deviation of .65499 at a significance level of .471 (Table 8). However, Hotel Group 3 has the highest mean (4.5714) and lowest standard deviation (.47246) when compared to other hotel groups. Hotel Group 4 recorded the highest mean score of 4.000 and the highest standard deviation of .77460 when compared to other hotel groups. This indicates that all hotel groups make use of internal business processes to grow shareholder value at the same level. It should be borne in mind that apart from saving diverse market segments, hotels have differentiated products and the internal business processes are harness so as to give the most value to the customer from whom all income is generated.

\subsubsection{Innovation and Learning Strategy}

The descriptive statistics and ANOVA of innovation and learning are highlighted in Table 9 and Table 10 below.

Table 9. Descriptive Statistics of Innovation and Learning Strategy

\begin{tabular}{|c|c|c|c|c|}
\hline & $\mathbf{N}$ & Mean & Std. Deviation & Std. Error \\
\hline Hotel Group 1 & 30 & 4.1000 & .80301 & .14661 \\
\hline Hotel Group 2 & 17 & 3.8382 & .80497 & .19523 \\
\hline Hotel Group 3 & 7 & 4.2857 & .68357 & .25836 \\
\hline Hotel Group 4 & 6 & 3.3333 & 1.29099 & .52705 \\
\hline Total & $\mathbf{6 0}$ & $\mathbf{3 . 9 7 0 8}$ & $\mathbf{. 8 6 4 9 1}$ & $\mathbf{. 1 1 1 6 6}$ \\
\hline
\end{tabular}

Table 10. Innovation and Learning Strategy ANOVA

\begin{tabular}{|c|c|c|c|c|c|}
\hline & $\begin{array}{c}\text { Sum of } \\
\text { Squares }\end{array}$ & df & $\begin{array}{c}\text { Mean } \\
\text { Square }\end{array}$ & F & Sig. \\
\hline $\begin{array}{c}\text { Between } \\
\text { Groups }\end{array}$ & 3.932 & 3 & 1.311 & 1.826 & .153 \\
\hline $\begin{array}{c}\text { Within } \\
\text { Groups }\end{array}$ & 40.205 & 56 & .718 & & \\
\hline Total & 44.136 & 59 & & & \\
\hline
\end{tabular}

The research indicates an overall mean of 3.9708 and standard deviation of .86491 on the utilisation of innovation and learning processes as strategies of adding shareholder value. Hotel Group 3 has the highest mean of 4.2857 and a standard deviation of .68357 , followed by Hotel Group 1 with a mean of 4.100 and standard deviation of .80301 , then Hotel Group 2 with a mean of 3.8382 , and finally Hotel Group 4 with a mean score of 3.3333 and the highest standard deviation of 1.29099 . However, the .153 level of significance recorded in Table 10 above prove that all hotels pay attention to the strong usage of innovation and business learning strategy. This may be due to the fact that in order to satisfy their customers, hotels have to learn their customer preferences, the best ways to satisfy their present customers, how other hotels are satisfying their customers, research and develop new products that when introduced will be embraced by the customers among other variables.

It follows then than hotels have to constantly learn from their micro and macro environment, adapt and keep ahead of the competition if they are to grow shareholder value.

\subsection{Research Question 2}

What is the perceived performance of hotels in terms of earnings per share, price earnings ratio, and dividend yield ratio?

The mean and standard deviation of innovation and learning are highlighted below in Table 11.

Table 11. Descriptive Statistics of Hotel Perceived Performance

\begin{tabular}{|c|c|c|c|}
\hline & $\mathrm{N}$ & Mean & Std. Deviation \\
\hline $\begin{array}{c}\text { Earnings per } \\
\text { share (EPS) }\end{array}$ & 60 & 3.7167 & 1.02662 \\
\hline $\begin{array}{c}\text { Price earnings } \\
\text { (PE) ratio }\end{array}$ & 60 & 3.7333 & 1.07146 \\
\hline $\begin{array}{c}\text { Dividend yield } \\
\text { ratio }\end{array}$ & 60 & 3.6500 & 1.03866 \\
\hline $\begin{array}{c}\text { Valid N } \\
\text { (list wise) }\end{array}$ & 60 & & \\
\hline
\end{tabular}

Price earnings ratio has benefited a lot from business shareholder growth strategies, with a mean of 3.7333 a standard deviation of 1.07146. Earnings per share recorded the second highest perceived shareholder growth performance indicator with a mean of 3.7167 and a standard deviation of 1.02662 .

Price earnings ratio has benefited a lot from business shareholder growth strategies, with a mean of 3.7333 a standard deviation of 1.07146. The dividend yield ratios were not far behind, with a mean of 3.6500 and a standard deviation of 1.03866 in as far as growing the shareholder value is concerned.

\subsection{Research Question 3}

Is there a relationship between hotel performance and the business strategies they are employing?

The correlation of hotel performance and strategy employed are highlighted below in Table 12. 
Table 12. Correlations of Hotel Performance and Strategy Employed

\begin{tabular}{|c|c|c|c|c|}
\hline & & $\begin{array}{c}\text { Earnings } \\
\text { per share } \\
\text { (EPS) }\end{array}$ & $\begin{array}{c}\text { Price } \\
\text { earnings } \\
(\mathrm{PE}) \text { ratio }\end{array}$ & $\begin{array}{c}\text { Dividend } \\
\text { yield ratio }\end{array}$ \\
\hline \multirow{3}{*}{$\begin{array}{c}\text { Financial } \\
\text { Strategy }\end{array}$} & $\begin{array}{c}\text { Pearson } \\
\text { Correlation }\end{array}$ & $.413 * *$ & $.313^{*}$ & $.496 * *$ \\
\hline & $\begin{array}{c}\text { Sig. (2- } \\
\text { tailed) }\end{array}$ & .001 & .015 & .000 \\
\hline & $\mathrm{N}$ & 60 & 60 & 60 \\
\hline \multirow{3}{*}{$\begin{array}{l}\text { Customer } \\
\text { Satisfaction }\end{array}$} & $\begin{array}{c}\text { Pearson } \\
\text { Correlation }\end{array}$ & $.651 * *$ & $.497 * *$ & $.553 * *$ \\
\hline & $\begin{array}{l}\text { Sig. (2- } \\
\text { tailed) }\end{array}$ & .000 & .000 & .000 \\
\hline & $\mathrm{N}$ & 60 & 60 & 60 \\
\hline \multirow{3}{*}{$\begin{array}{c}\text { Internal } \\
\text { Business } \\
\text { Process }\end{array}$} & $\begin{array}{c}\text { Pearson } \\
\text { Correlation }\end{array}$ & $.689 * *$ & $.599 * *$ & $.544 * *$ \\
\hline & $\begin{array}{l}\text { Sig. (2- } \\
\text { tailed) }\end{array}$ & .000 & .000 & .000 \\
\hline & $\mathrm{N}$ & 60 & 60 & 60 \\
\hline \multirow{3}{*}{$\begin{array}{l}\text { Innovation } \\
\text { and } \\
\text { Learning }\end{array}$} & $\begin{array}{c}\text { Pearson } \\
\text { Correlation }\end{array}$ & $.592 * *$ & $.444 * *$ & $.460 * *$ \\
\hline & $\begin{array}{l}\text { Sig. (2- } \\
\text { tailed) }\end{array}$ & .000 & .000 & .000 \\
\hline & $\mathrm{N}$ & 60 & 60 & 60 \\
\hline
\end{tabular}

**. Correlation is significant at the 0.01 level (2-tailed)

*. Correlation is significant at the 0.05 level (2-tailed)

In this study performance was measured by EPS, PE ratio, and dividend yield ratio, and the strategies employed were financial, customer satisfaction, internal business processes, and innovation and learning all yielding the following results:

\subsubsection{Earnings per Share (EPS)}

EPS were mostly influenced by internal business process with a correlation of .689 , followed by customer relation with a correlation of .651 . Innovation and learning strategies correlation of .592 and financial strategies correlation of .413 were third and forth respectively. To better satisfy the target market, companies should identify their market segments and work on growing their market share, customer retention, customer acquisition, customer satisfaction, and customer profitability measurements.

Tourism is the fastest growing industrial sector in the world. The need by many countries to grow their economies after the devastating effects of the global recession in 2009 has brought fierce completion among countries. For companies to be effective in such difficult environments, they need to develop novel business models by improving their internal business processes. In order for organisations to thrive, managers must have a good understanding of how their business models work. Thus they have to improve their business processes, improve on customer satisfaction, be innovative and learn from other industrial players, then have an effective financial strategy in place to quantify and collate the monetary benefits that accrue.

In Zimbabwe, between 2000 and 2008, tourism, like all other industrial sectors in Zimbabwe, was on a downward spiral with little capital investment or otherwise coming into the sector. When the government introduced a multicurrency economy in 2009, hotel profitability steadily improved and the resultant profits ploughed back into the sector to improve on service quality and delivery, while growing shareholder value.

\subsubsection{Price Earnings (PE) Ratio}

As if following the same pattern, the PE ratio was largely influenced by internal business processes with a correlation of .599 , customer relations correlation of .497 , innovation and learning correlation of .444 , and financial strategies with a correlation of .313. Considering that there is a high negative correlation between the perceived growth of the PE ratio and the EPS.

The fraction of companies paying cash dividends have fallen substantially in recent decades and the PE ratio is assuming a more fundamental role as an indicator of value. This is no surprise since shareholder value is maximised through the cash they receive in dividend payment and capital gains arising from increasing share price, hence tourism and hospitality companies in Zimbabwe have not paid out any cash dividends in over a decade, but have retained the profits so as to shore up the PE ratio. Investors perceive hotel group to have greater prospects of capital gains in the medium to long term horizon, raising the $\mathrm{PE}$ ratio.

Zimbabwe's tourism and hospitality industry is on the rebound, and is expected to become one of the world's fastest growing sectors between 2011 and 2021, with a growth rate of 6,9 percent per annum and annual revenue earnings of over US\$850 million. Huge investments in the sector, the rights to co-host the UNWTO congress in 2013 , and the drafting of the Victoria Falls Tourism Master Plan has helped raise the expected future earnings from the sector. To underpin this, hotel groups have given sustained attention to improving their business processes, customer satisfaction, and innovation and learning so as to grow shareholder value.

\subsubsection{Dividend Yield Ratio}

Dividend yield has been largely influenced by customer relations with a correlation of .553 , followed by internal business processes correlation of .544 , financial strategies with a correlation of .496 , while innovation and learning strategies with a correlation of .460 .

Setting up a hotel requires huge capital resources and the providers of this capital need assurance that once developed, the hotel will attract enough business to generate the expected returns from which dividends are paid to the capital providers. The most obvious way of attracting hotel business is by satisfying the needs of the current customers. It should be borne in mind that the business operating environment is now more volatile, and companies are redesigning their business processes in order to become more competitive. Customer satisfaction then becomes a key factor in generating income streams from which dividends are paid to investors. A majority of business CEOs believe that a sharp decline in customer satisfaction or retention would affect performance and profitability.

Investors use dividend yield growths as a hedge against future inflation. Managers, on the other hand, pay high dividends to signal their confidence in the growth and stability and future earnings of the company. In order to consolidate this growth, customer satisfaction, internal business processes, financial strategy, and innovation and learning are all harnessed to consolidate the business gains.

\subsection{Research Question 4}

\section{What factors affect hotel performance?}




\subsubsection{Earnings per Share (EPS)}

The model summary and coefficient of factors affecting earnings per share are given below in Table 13 and Table 14.

Table 13. Model Summary of Factors Affecting EPS

\begin{tabular}{|c|c|c|c|c|}
\hline Model & $\mathrm{R}$ & $\begin{array}{c}\mathrm{R} \\
\text { Square }\end{array}$ & $\begin{array}{c}\text { Adjusted R } \\
\text { Square }\end{array}$ & $\begin{array}{c}\text { Std. Error of } \\
\text { the Estimate }\end{array}$ \\
\hline $\begin{array}{c}\text { Internal } \\
\text { Business } \\
\text { Process }\end{array}$ & $.689^{\mathrm{a}}$ & .474 & .465 & .75079 \\
\hline $\begin{array}{c}\text { Customer } \\
\text { Satisfaction }\end{array}$ & $.763^{\mathrm{b}}$ & .583 & .568 & .67481 \\
\hline
\end{tabular}

a. Predictors: (Constant), internal

b. Predictors: (Constant), internal, customer

Table 14. Coefficients of Factors Affecting EPS

\begin{tabular}{|c|c|c|c|c|c|}
\hline \multirow{2}{*}{ Model } & \multicolumn{2}{|c|}{$\begin{array}{c}\text { Unstandardized } \\
\text { Coefficients }\end{array}$} & \multirow{2}{*}{$\begin{array}{c}\begin{array}{c}\text { Standardized } \\
\text { Coefficients }\end{array} \\
\text { Beta }\end{array}$} & \multirow{2}{*}{$\mathrm{t}$} & \multirow{2}{*}{ Sig. } \\
\hline & B & $\begin{array}{c}\text { Std. } \\
\text { Error }\end{array}$ & & & \\
\hline \multirow{2}{*}{$\begin{array}{l}\text { 1(Constant) } \\
\text { internal }\end{array}$} & -.875 & .642 & & -1.363 & .178 \\
\hline & 1.079 & .149 & .689 & 7.233 & .000 \\
\hline \multirow{3}{*}{$\begin{array}{c}\text { 2(Constant) } \\
\text { internal } \\
\text { customer }\end{array}$} & -1.905 & .636 & & -2.994 & .004 \\
\hline & .745 & .160 & .475 & 4.662 & .000 \\
\hline & .582 & .151 & .392 & 3.847 & .000 \\
\hline
\end{tabular}

a. Dependent Variable: Earnings per share (EPS)

There were two factors that affected EPS, internal business processes and customer satisfaction. Internal business processes contributed $46.5 \%$ of the effect on a beta of .689. The more internal process strategies were applied, the higher the EPS. Every hotel has a vision that it seeks to achieve. To generate superior earnings, the research hotel managers carefully designed internal business processes that allow them to know how well their businesses are running and whether their products and services conform to customer requirements and by so doing uniquely match with the hotels vision.

Customer satisfaction contributed $10.3 \%$ of the value in EPS with a beta of .392. The more customer satisfaction strategy was applied, the higher the EPS. The hotel business is more of satisfying the customer. Customers drive earnings and if they are not satisfied, they search for other hotels that will meet their needs. To grow future earnings, hotels need to satisfy the current customer since poor customer focus leads to a decline in future earnings even though the current financial picture may look good.

Recent management approaches focus on customer satisfaction in any business by seeking to understand their customer wants. The study has proved that individual hotel groups select their preferred market niche and they do well to perfect their processes to the satisfaction of these customers.

\subsubsection{Price Earnings (PE) Ratio}

The model summary and coefficient of factors affecting earnings per share are given below in Table 15 and Table 16.

Table 15. Model Summary of Factors Affecting PE Ratio Growth

\begin{tabular}{|c|c|c|c|c|}
\hline Model & $\mathrm{R}$ & $\begin{array}{c}\mathrm{R} \\
\text { Square }\end{array}$ & $\begin{array}{c}\text { Adjusted R } \\
\text { Square }\end{array}$ & $\begin{array}{c}\text { Std. Error of } \\
\text { the Estimate }\end{array}$ \\
\hline $\begin{array}{c}\text { Internal business } \\
\text { process strategy }\end{array}$ & $.599^{\mathrm{a}}$ & .359 & .348 & .86505 \\
\hline
\end{tabular}

a. Predictors: (Constant), internal
Table 16. Coefficients of Factors Affecting PE Ratio Growth

\begin{tabular}{|c|c|c|c|c|c|}
\hline \multirow{3}{*}{ Model } & \multicolumn{2}{|c|}{$\begin{array}{c}\text { Unstandardized } \\
\text { Coefficients }\end{array}$} & $\begin{array}{c}\text { Standardized } \\
\text { Coefficients }\end{array}$ & \multirow{2}{*}{$\mathrm{t}$} & \multirow{2}{*}{ Sig. } \\
\cline { 2 - 6 } & $\mathrm{B}$ & $\begin{array}{c}\text { Std. } \\
\text { Error }\end{array}$ & & & \\
\hline $\begin{array}{c}1 \text { (Constant) } \\
\text { internal }\end{array}$ & -.438 & .740 & & -.591 & .556 \\
\cline { 2 - 6 } & .980 & .172 & .599 & 5.702 & .000 \\
\hline
\end{tabular}

a. Dependent Variable: Price earnings (PE) ratio

The internal business process is the only factor that affected PE ratio, contributing $34.8 \%$ and a beta of .599 . The more internal business process strategy was applied, the higher the PE ratio.

In the balanced scorecard, internal business processes has a bigger weight than other perspectives. This is indicative of the importance of internal processes in growing shareholder value. More importantly internal business process strategy enables organizations to align all levels of staff around a single strategy so that it can be executed more successfully.

For a company to succeed, it has to identify those business processes that are critical for success. This will allow managers to know how to develop work processes that minimize costs while maximizing in quality and match with the companies vision and mission. It is no surprise then that the $\mathrm{PE}$ ratio is driven mostly by improvements in internal business processes as hotels try to improve the market value of their shares and EPS.

\subsubsection{Dividend Yield Ratio}

The model summary and coefficient of factors affecting earnings per share are given below in Table 17 and Table 18.

Table 17. Model Summary of Factors Affecting Dividend Yield Growth

\begin{tabular}{|c|c|c|c|c|}
\hline Model & $\mathrm{R}$ & $\mathrm{R}$ Square & $\begin{array}{c}\text { Adjusted R } \\
\text { Square }\end{array}$ & $\begin{array}{c}\text { Std. Error of } \\
\text { the Estimate }\end{array}$ \\
\hline $\begin{array}{c}\text { Customer } \\
\text { satisfaction }\end{array}$ & $.553^{\mathrm{a}}$ & .306 & .294 & .87285 \\
\hline $\begin{array}{c}\text { Financial } \\
\text { strategy }\end{array}$ & $.660^{\mathrm{b}}$ & .436 & .416 & .79367 \\
\hline
\end{tabular}

a. Predictors: (Constant), customer

b. Predictors: (Constant), customer, fin strategy

Table 18. Coefficients of Factors Affecting Dividend Yield Growth

\begin{tabular}{|c|c|c|c|c|c|}
\hline \multirow{2}{*}{ Model } & \multicolumn{2}{|c|}{$\begin{array}{c}\text { Unstandardized } \\
\text { Coefficients }\end{array}$} & \multirow{2}{*}{$\begin{array}{c}\text { Standardized } \\
\text { Coefficients } \\
\text { Beta }\end{array}$} & \multirow{2}{*}{$\mathrm{t}$} & \multirow{2}{*}{ Sig. } \\
\hline & B & $\begin{array}{l}\text { Std. } \\
\text { Error }\end{array}$ & & & \\
\hline \multirow{2}{*}{$\begin{array}{c}1 \\
\text { (Constant) } \\
\text { customer }\end{array}$} & .153 & .701 & & .218 & .829 \\
\hline & .831 & .164 & .553 & 5.054 & .000 \\
\hline \multirow{3}{*}{$\begin{array}{l}2 \text { Constant) } \\
\text { customer } \\
\text { fin strategy }\end{array}$} & -1.226 & .742 & & -1.651 & .104 \\
\hline & .679 & .155 & .452 & 4.381 & .000 \\
\hline & .525 & .145 & .374 & 3.626 & .001 \\
\hline
\end{tabular}

a. Dependent Variable: Dividend yield ratio

\section{Conclusion and Recommendations}

The study concludes that hotels in Zimbabwe employ both financial and non-financial strategies in achieving shareholder value growth and EPS is the superior measure of performance. Further, there is a relationship between hotel performance and strategies employed. Internal business process and customer satisfaction strategy had a bearing on the performance of EPS, while dividend yield growth ratio was affected by customer satisfaction and financial strategy. PE ratio, on the other hand, was affected by one factor only: internal business process 
strategy. Overall, internal business process strategy has been proven to have the strongest relationship while financial strategy has the weakest relationship. There is a significant relationship between hotels shareholder value growth and the business strategies employed.

The researcher recommends that manager focus more on customer satisfaction since it is these satisfied customers who generate repeat business and referrals, which in turn improve the profit margin; the reverse is true for unhappy customers. Managers should identify the internal business processes that should be continuously improved so as to enable the hotels to deliver superior service to its customers, present and prospective. Further, hotels should strengthen the use of financial ratios to evaluate progress towards the achievement of established goals, and compare these ratios to those for the market or industry as whole. Satisfied customers increase hotel earnings, and these have a positive correlation with the dividend yield ratio.

Finally the researcher recommends further future studies to replicate the results of this study in other industrial sectors in the Zimbabwean economy. There is also need for more inclusive studies that will involve a bigger sample size, and secondary data in the hotel industry to compare the perceived performance with actual performance over a long time period, that is, longitudinal studies.

\section{References}

[1] Cooper, D. R, and Schindler, P. S, "Business Research Methods", $8^{\text {th }}$ Edition, Tata McGraw-Hill, 2005.

[2] Muchapondwa, E and Pimhidzai, O, "Modeling International Tourism Demand for Zimbabwe", International Journal of Business and Social Science, Volume, 2(2), 71-8, 2011.

[3] Cooper, D. R, Schindler, P. S, "Business Research Methods", $8^{\text {th }}$ edition, Tata McGraw-Hill Publishing Company, 2005.

[4] Mbaiwa, J. E, "The Socio-Economic and Environmental Impacts of Tourism Development on the Okavango Delta, North-Western Botswana", Journal of Arid Environments, Volume, 54, 447-467, 2003.

[5] Atrill, P, "Financial Management for Decision Makers", $5^{\text {th }}$ edition, Pearson Education, 2009.

[6] Christie, I. T, and Crompton, D. E, "Tourism in Africa: Africa Region Working Paper Series", World Bank, Washington DC, 2001.

[7] Sundaram, A. K., and Inkpen, A. C, "The Corporate Objective Revisited", Organisation Science, Volume, 15(3), 350-363, 2004.

[8] Artley, W, and "The Performance-Based Management", Handbook: Establishing an Integrated Performance Measurement System, Volume 2, University of California, 2005.

[9] Copeland et al., "Valuation: Measuring and Managing the Value of Companies", John Wiley \& Sons Inc, 2000.

[10] Boaz Ronen, Z. L and Nitza, G, "Value Focused Management (VFM): Capitalizing on the Potential of Managerial Value Drivers", IOS Press, 149-151, 2007.

[11] Awoniyi, S. A., Aderanti, R. A and Tayo, A. S, "Introduction to Research Methods", Ababa Press Limited, 2011.

[12] Amit, R and Zott, C, "Value Creation in E-Business', Strategic Management Journal, Volume 22 (6/7), 493-520, 2001.

[13] Nieuwenhuizen, C, "Business Management for Entrepreneurs', Juta \& Co, Cape Town, 2007.

[14] Babbie, E "The Practice of Social Research', 12th edition. Canada, Wadsworth Publishing, 2009.

[15] Aaker, K and Day, R "Marketing Research", $7^{\text {th }}$ Edition, John Wiley \& Sons, NY, 2001.

[16] Anne A, Geert S, and Werner, B "Value Based Management: An Integrated Approach to Value Creation", Vlerick Leuven Gent Management School, 2002.
[17] Breakwell, G. M, Hammond, S and Fife-Schaw, C, "Research Methods in Psychology", $2^{\text {nd }}$ edition, SAGE Publications, 2004.

[18] Shulver, M, Lawrie, G, and Andersen, H, "A Process for Developing Strategically Relevant Measures of Intellectual Capital", Proceedings, 2nd International Conference on Performance Measurement, Cambridge, UK, 2000.

[19] Bourne, M, Hudson, M, Lean, J and Smart, P, "Only Just Managing - No Time to Measure', Neely, A. (ed.), Performance Measurement: Past, Present and Future, University of Cambridge: Bedfordshire, Cranfield School of Management, 243-250, 2000.

[20] Saunders, M, Lewis, P and Thornhill, A, "Research Methods for Business Students', Prentice Hall, London, 2007.

[21] Stern, J. M, and Shiely, J. S, "The EVA ® Challenge", John Wiley \& Sons, New York, NY (2001),

[22] Correia, C, Flynn, D, Uliana, E and Wormold, M, "Financial Management", $4^{\text {th }}$ edition, Juta \& co. Ltd, South Africa, 2000.

[23] Steven, M and Tony, T, "Organisational Behaviour on the Pacific Rim”, McGraw-Hill Pty Ltd, Australia, 2003.

[24] Swink, M, Melnyk, S. A, Cooper, M. B, and Hartley, J. L, "Managing Operations Across the Supply Chain", McGraw-Hill Irwin, 2011.

[25] Cresswell, J. C, "Research Design, Qualitative, Quantitative, and Mixed Methods Approaches", 2nd edition, Thousand Oaks, Sage Publications, New Delhi, 2003.

[26] Brealey, R. A, Myers, S. C, and Marcus, A. J, "Fundamentals of Corporate Finance", $3^{\text {rd }}$ edition, McGraw-Hill Companies, Inc, 2001.

[27] Ulwick, A. W, "Turning Customer Input into Innovation", Havard Business Review, Volume 8(1), 91-97, 2001.

[28] David, S.Y and Stephen F, and O'Byrne, E "Value-Based Management; A Practical Guide to Implementation", McGrawHill, 2000 as quoted in www.getabstract.com, 2003.

[29] United Nations World Tourism Organisation (UNWTO), "Tourism Trends", 2005 Edition, UNWTO, New York, 2006.

[30] Williams, J, Haha, S, Bettner, M, and Carcello, J, "Financial and Managerial Accounting: The Basis for Business Decisions", $15^{\text {th }}$ edition, McGraw-Hill, Irwin, 2010.

[31] Charles W. L. H and Gareth R. J, "Strategic Management", Houghton Mifflin, 2001.

[32] Chenhall, R. H and Chapman, C, "Theorising and Testing Fit in Contingency Research on Management Control Systems", In Hoque, Z. (ed.), and Methodological Issues in Accounting Research: Theories and Methods, Spiramus, London, 2006.

[33] Wood, F and Sangster, A, "Business Accounting 2", Pearson Educational Limited, UK, 2005.

[34] Brealey, R. A., Myers, S. C, Allen, F, and Mohanty, P, "Principles of Corporate Finance", $8^{\text {th }}$ edition, Tata McGraw-Hill Publishing Company Limited, 2007.

[35] Bates, R. G, Dempster, M. A. H, Go, H. G and Yong, Y. S, "Prospective Earnings per Share", University of Cambridge, WP 06/2004, 2004.

[36] Zikmund, W. G and Babin, B. J, "Essentials of Marketing Research", $3^{\text {rd }}$ edition, Thompson South-Western, 2007.

[37] Reisinger, H, Cravens, K. S and Tell, N, "Prioritizing Performance Measures Within the Balanced Scorecard Performance Framework", Management International Review, Volume 43(4), 429-437, 2003.

[38] Roseline, T, Karambakuwa, T, Shonhiwa, L, Murombo, F. N, Mauchi, N, Gopo, R. W, Denhere, F, Tafirei, A and Victoria, M, "The Impact of Zimbabwe Tourism Authority Initiatives on Tourist Arrivals in Zimbabwe (2008 - 2009)", Journal of Sustainable Development in Africa, Volume 13(6), 2011.

[39] Denzil, W, Antony, H, "Corporate Finance Principles and Practice", Pearson Education Limited, Prentice Hall, $3^{\text {rd }}$ Edition, 2004.

[40] Rosenthal, R and Rosnow, R. L, "Essentials of Business Research: Methods and Data Analysis", $3^{\text {rd }}$ Edition, McGraw-Hill, NY, 2008.

[41] Bender, R and Ward, K, "Corporate Financial Strategy", $3^{\text {rd }}$ Edition, 2008.

[42] Estrada, J "Adjusting P/E ratios by growth and risk: the PERG ratio", International Journal of Managerial Finance, Volume 1(3), 187-20, 2005

[43] Henri, J, "Organisational Culture and Performance Measurement Systems", Accounting, Organisation \& Society, Volume 31, 77103, 2006.

[44] Gomes, C, Mahmoud, Y. M and Lisboa, J "An Examination of Manufacturing Organisations, Performance Evaluation: Analysis, 
Implications and a Framework for Future Research”, International Journal of Operations and Production Management, Volume 24(5), 488-513, 2004.

[45] Zikmund, W. G, "Business Research Methods", 7th edition, Thomson South-Western, Ohio, 2003.

[46] Chong, H. G, "Measuring Performance of Small and MediumSized Enterprises: The Grounded Theory Approach", Journal of Business and Public Affairs, Volume 2, (1), 2008.

[47] Morse, J. M, Barrett, M, Mayan, M, Olson, K and Spiers, J, "Verification Strategies for Establishing Reliability and Validity in Qualitative Research", International Journal of Qualitative Methods, Volume 1(2), 13-22, 2002.

[48] Franklin, A, "Econometrics", Oxford Review of Economic Policy, Volume 21(2), 2005.

[49] Mouton, J, "How to succeed in your Master's \& Doctoral studies", Van Schaik Publishers, Pretoria, 2001.
[50] Otley, D. T, "Management Control and Performance Management: Whence and Whither?" British Accounting Review, Volume 35, 309-326, 2003

[51] Mitchell, M. L, and Jolley, J. M, "Research Design Explained", $6^{\text {th }}$ edition, Belmont, CA: Thomson Wadsworth, 2007.

[52] Olve, N, Roy, J and Wetter, M, "Performance Drivers: A Practical Guide to Using the Balanced Scorecard", John Wiley \& Sons, NY, 2001.

[53] Ittner, C. D and Larcker, D. F, “Assessing Empirical Research in Managerial Accounting: A Value Based Management Perspective", Journal of Accounting and Economics, Volume 32 (1-3), 349-410, 2001.

[54] Hoque, Z. A, "Contingency Model of the Association between Strategy, Environmental Uncertainty and Performance Measurement: Impact on Organisational Performance", International Business Review, Volume 13, 77-103, 2004. 